\title{
BETA-CAROTENE AND VITAMIN A CONTENT IN BLOOD PLASMA AND THE LIVER OF SLAUGHTER BUFFALOES IN DIFFERENT SEASONS OF THE YEAR IN AHVAZ (IRAN)
}

\author{
Ghadrdan Mashhadi A., Jalali M.R., Mostashar N.B. \\ Faculty of Veterinary Medicine, Sh. Chamran University, Ahvaz, Iran
}

Vitamin A is one of the most important fat-soluble vitamins. Because of its particular role in different tissues and organs, in deficiency conditions various clinical signs are seen. In addition sometimes the marginal deficiency is present and clinical signs are not visible but performance defects such as infertility is seen.

In some regions of Iran, buffalo is breading for production of milk and meat. In large animal, much study about beta-carotene and vitamin $\mathrm{A}$ is done in cow and information about buffalo is little. In present study, seasonal changes of vitamin A and beta-carotene in serum and liver of 120 buffaloes was investigated in Ahvaz slaughterhouse (Iran), between May 1998-April 1999. We, also, selected animals from 2 sexes and divided them to the 5 age groups (less than 2 , 2-3 , 3-4, 4-5 and more than 5 yrs old).

Spectrophotometery was used for measuring vitamin A and beta-carotene. The results were analyzed statistically with multifactorial repeated measures ( ANOVA) and Pearson's correlations. Results showed that the values of mean of serum and liver vitamin A and serum and liver beta-carotene. $(69.01 \pm 2.23 \mu \mathrm{g} / \mathrm{dl}, 111.99 \pm 6.42 \mu \mathrm{g} / \mathrm{gr} 21.43 \pm 2.21 \mu \mathrm{g} / \mathrm{dl}, 23.19 \pm 2.23 \mu \mathrm{g} / \mathrm{gr}$ respectively $)$ are similar to normal ranges in cows. These values in different seasons, age groups and 2 sexes were normal, too.

There wasn't significant difference between vitamin A and beta- carotene values of the serum and livers for both the 2 sexes and age groups.

We couldn't find any similar study about the effect of sex and age groups on vitamin A and betacarotene content in Buffalo. Rather, these findings are not in accordance with the results of previous studies in cow.

However, the was significant seasonal variations in serum vitamin A ( max in autumn and min in spring) and liver vitamin A ( max in spring and min in winter). The difference between seasons serum vitamin $\mathrm{A}$ is similar to those reported in similar studies performed in Yugoslavia. There wasn't significant difference between different seasons serum and liver beta carotene .

\section{References}

Ibrovic M. et al(1972). Carotene metabolism and seasonal changes in vitamin A in the buffalo (Bos bubalis). Veterinaria Yugoslavia, 21(4): 511-515

Suzuki J. and Katoh N.(1990). A simple and cheep method for measuring serum vitamin A in cattle- using only a spectrophotometer. Jpn. J. Vet. Sci., 52: 1281-1283 